Research Article

\title{
Analysis of the Anomalous Signals near the Tropopause before the Overshooting Convective System Onset over the Tibetan Plateau
}

\author{
Hongying Tian (D, ${ }^{1}$ Xiran Xu, ${ }^{1}$ Hongbao Chen, ${ }^{2}$ Rui Huang, ${ }^{1}$ Shiyan Zhang, ${ }^{1}$ and Jiali Luo ${ }^{1}$ \\ ${ }^{1}$ Key Laboratory for Semi-Arid Climate Change of the Ministry of Education, College of Atmospheric Sciences, \\ Lanzhou University, Lanzhou 730000, China \\ ${ }^{2}$ Water Resources and Hydropower Investigation, Design and Research Institute Co., Ltd., Gansu, Lanzhou 730000, China \\ Correspondence should be addressed to Hongying Tian; tianhy@lzu.edu.cn
}

Received 27 June 2020; Accepted 3 September 2020; Published 17 September 2020

Academic Editor: Luis Gimeno

Copyright (c) 2020 Hongying Tian et al. This is an open access article distributed under the Creative Commons Attribution License, which permits unrestricted use, distribution, and reproduction in any medium, provided the original work is properly cited.

\begin{abstract}
This study investigates the anomalous signals near the tropopause before the overshooting convective system (OCS) onset over the Tibetan Plateau (TP). It is found that the tropopause height is stable at the maximum height for the 7 th day and the 5 th day before the OCS onset. It then decreases significantly one day before and on the day of the OCS onset. The upward motion in the troposphere is the strongest for the 5th day before the OCS onset. From one day before and after the OCS onset, there are strong ascending motions at 500-300 $\mathrm{hPa}$ but weak descending motions near the tropopause. It is proposed that the descending of the tropopause height on the day of the OCS onset is caused by frequent tropopause fold events over the eastern TP associated with frequent cold trough intrusion from the north and the southeastward movement of upper-level westerly jet stream. The decrease of the tropopause height is accompanied by the intrusion of stratospheric air with higher potential vorticity (PV). Positive potential vorticity anomalies on $350 \mathrm{~K}$ isentropic surface can be noted in the region where the tropopause height decreases one day before and on the day of the OCS onset. With the deepening of the tropopause fold on the day of the OCS onset, there is not only downward motion near the tropopause in the area behind of the fold but also upward motion in the troposphere beneath the folding region. In addition, the upward displacement of isentropic surfaces leads to an upper-level cold pool, which causes a reduction in static stability beneath the PV anomaly on the day of the OCS onset. The upper-level PV anomalies and their associated strong instability in the middle troposphere can trigger convective activities by the release of potential instability on the day of the OCS onset. The overshooting convection is more likely to occur due to lower tropopause height, although upward motion in the troposphere is not the strongest.
\end{abstract}

\section{Introduction}

The deep convection can effectively redistribute trace gases throughout the atmosphere by changing the trace gas composition and thus plays an important role in the stratosphere-troposphere exchange (STE) [1-3]. Observational evidences show that deep convection at high altitude can be strong enough to penetrate the tropopause and rise into the stratosphere (hereinafter referred to as overshooting convective system (OCS)), which directly injects water vapor, pollutants, and even ice crystals into the stratosphere $[4,5]$. Recently, Sang et al. [6] proposed that overshooting convective activities increase water content in the lower stratosphere, which is a result of the sublimation of ice crystals that pass through the tropopause and mix with the warmer stratospheric air. The increase in the stratospheric water vapor can intensify the global greenhouse forcing [7] and enhance ozone depletion $[8,9]$, which will subsequently affect the radiation budget and surface temperature [10].

The Tibetan Plateau (TP) is the highest landmass in the world and exerts profound impacts upon global climate change and the formation of weather disasters [11-13]. Many previous studies have focused on the mechanism for the formation of low total column ozone [14-17] and the stratosphere-troposphere exchange over the TP [18-29]. It is found that deep convection in the Tibetan Plateau-Asian monsoon region plays a critical role in cross-tropopause transport of chemical tracers during boreal summer [22-24]. 
Luo et al. [25] conducted a comprehensive study on deep convection over different regions of the Tibetan Plateau-Asian monsoon region and showed that the cloud tops over the TP are more densely packed than the other subregions. Qie et al. [2] found that deep convective systems with $20 \mathrm{dBZ}$ echo tops exceeding $14 \mathrm{~km}$ occur frequently over the TP. Heath and Fuelberg [26] defined convective trajectories as those that started at the upper-level anticyclone and reached the top of the boundary layer at some time during their $6 \mathrm{~h}$ back track, and they revealed that more than $90 \%$ of convective trajectories originated in the TP and the southern slope of the Himalayas at both 100 and $150 \mathrm{hPa}$. On the other hand, the STE associated with the tropopause folds accounts for a large proportion of total STE over the TP $[27,28]$. Tropopause folds can cause stratospheric air to be transported downwards to the atmospheric boundary layer and influence the vertical distribution of tropospheric greenhouse gases such as ozone over the TP [27-29]. Because tropopause folds are associated with development of upperlevel positive potential vorticity (PV) anomalies, they could possibly contribute to rapid cyclogenesis, deep convective storms, and other severe weather events [30, 31]. Considerable progress has been made in understanding the formation of deep convection over the TP. The complex terrain and unique thermal and dynamical forcing of the TP make it an active region of strong summer convective systems $[18,22]$. As the low-level layer of warm and moist air from the Arabian Sea and the Bay of Bengal over the Indian subcontinent is obstructed by the steep mountain barrier, it is capped by an elevated layer of dry air advected off the Iranian or Tibetan Plateaus. The capped low-level monsoon airflow accumulates instability via surface heating over the TP $[32,33]$. Furthermore, the westerly jet stream moves to northern TP in summer from the southern TP in winter. The lee side of the Tibetan Plateau has been identified as one of the two maxima for the development of baroclinic disturbances and cyclogenesis in the extratropical Northern Hemisphere, which is beneficial to the occurrence of synoptic-scale weather systems [34]. Nevertheless, the mechanism for the formation of overshooting convective systems over the TP has not been fully understood yet.

Traditionally, the stratosphere is considered to be a passive layer that is affected by the troposphere, and it has little influence on the surface weather systems. However, the circulation regimes in the stratosphere tend to persist for several weeks or longer. Observations suggest that large stratospheric anomalies can be used as a predictor of tropospheric weather patterns [35-39]. Hartley et al. [40] and Black [41] found that anomalous changes in stratospheric potential vorticity $(\mathrm{PV})$ can induce perturbations in key meteorological fields in the upper troposphere and thus have important influences on synoptic systems in the troposphere. Colucci [38] proposed that the midtropospheric anticyclogenesis associated with the blocking case critically depends on the stratospheric contribution and should not be solely explained by tropospheric processes. Luo et al. [42] found that the Northern Hemisphere Annular Mode (NAM) index near the tropopause region is one of the good factors for forecasting precipitation in the Meiyu season. At present, results of numerical models also indicate that the tropospheric weather systems can be better simulated when the representations of the stratosphere and stratospheric processes are improved in models [43-46]. It can be seen that an improved understanding of the dynamical link between the stratosphere and the troposphere is expected to lead to improved confidence in both long-range weather forecasts and climate change projections [47].

However, the anomalous signals around the tropopause and in the stratosphere before the onset of the overshooting convective system over the TP have not been fully analyzed in previous studies. The present study aims to investigate temporal and spatial variations of the tropopause height, the potential vorticity, and meteorological fields before the overshooting convective systems onset and to find out the anomalous signals in the tropopause and lower stratosphere before the overshooting convective systems onset over the Tibetan Plateau. This paper is organized as follows. Section 2 describes the data and method used in this study. Section 3 presents the results. Summary and discussion are given in Section 4.

\section{Data and Methods}

The characteristics of convective systems are identified based on the $16 \mathrm{yr}$ period (1998-2013) of Tropical Rainfall Measuring Mission (TRMM) radar precipitation feature (PF) level 2 data downloaded from the University of Utah database [48]. The method to define radar PFs by grouping the area of ground projection of radar reflectivity greater than or equal to $20 \mathrm{dBZ}$ is adopted in the present study [48, 49]. However, the data for August 2001, when the TRMM satellite's orbit was boosted to lengthen its mission, are excluded due to concerns of the data quality and reliability during this period [50]. As the first quantitative spaceborne radar, the TRMM precipitation radar $(\mathrm{PR})$ provides $3 \mathrm{D}$ structural features of precipitation systems. The TRMM PR has horizontal resolutions of $4.3 \mathrm{~km}$ (before the orbit boost in August 2001) and $5 \mathrm{~km}$ (after the boost). It has a $215 \mathrm{~km}$ swath width that extends from the surface to $20 \mathrm{~km}$ above the Earth ellipsoid with the vertical resolution of $250 \mathrm{~m}$ [49]. The erroneous TRMM PF cases described by Qie et al. [2] are excluded.

The TRMM PF dataset is used to identify deep convective systems reaching above the tropopause height. The maximum height of $20 \mathrm{dBZ}$ radar echo (Maxht20) is an indicator of the PF depth [51, 52]. The reference height to define overshooting convective system (OCS) is determined according to WMO lapse rate tropopause height definition [53] in this study, which is defined as the lowest level at which the lapse rate decreases to $2 \mathrm{~K} \mathrm{~km}^{-1}$ or less, provided that the average lapse rate remains less than $2 \mathrm{~K} \mathrm{~km}^{-1}$ for $2 \mathrm{~km}$ above this level. This is also one of the methods used by Liu and Liu [54]. Several previous studies have demonstrated that the lapse rate tropopause height derived from the ERAInterim analysis is suitable for such efforts [55]. In this study, we use the $0.25^{\circ} \times 0.25^{\circ}$, 6-hourly ERA5 reanalysis data with better spatial and temporal resolution, which allows for a better representation of convective updrafts, gravity waves, 
tropical cyclones, and other meso- to synoptic-scale features of the atmosphere [56]. Because the ERA5 analyses of lower stratospheric temperature exhibit a pronounced cold bias from the years 2000-2006 [57], we replace the temperature using $0.25^{\circ} \times 0.25^{\circ}$, 6-hourly ERA5.1 reanalysis with better global-mean temperatures in the stratosphere and uppermost troposphere during 2000-2006. First, the lapse rate tropopause height derived $0.25^{\circ} \times 0.25^{\circ}, 6$-hourly ERA5 and ERA5.1 data are temporally and spatially interpolated to the time and location of each PF. Second, the vertical profile for each $\mathrm{PF}$ is interpolated into $0.1 \mathrm{~km}$ intervals to calculate the lapse rate tropopause height according to the WMO definition. Then, the overshooting convective systems are defined by TRMM PFs with Maxht20 reaching above the lapse rate tropopause height. In total, 41 OCS events are found over the TP in the summers (June, July, and August) during 1998-2013. The detail dates about 41 OCS events are listed in Table 1. Figure 1(a) shows geographical locations of the 41 OCS events in summer over the TP based on 16 years of TRMM observations. We can note that the OCS events are mainly found over the eastern TP from Figure 1(a). The scatter plot of Maxht20 and tropopause height derived from 41 OCS events are shown in Figure 1(b); the average values of Maxht20 and tropopause height are $17.28 \mathrm{~km}$ and $16.78 \mathrm{~km}$ above the sea level, respectively.

A composite analysis is performed with respect to days before and after the onset of OCS events. Note that all the meteorological fields, including tropopause height, potential vorticity, temperature, zonal and meridional winds, geopotential height, and vertical velocity, are temporally and spatially interpolated to the time and location of 41 OCS using $0.25^{\circ} \times 0.25^{\circ}$, 6-hourly ERA5 and ERA5.1 reanalysis data. The composite field on the $n$th day before (or after) the onset of OCS events is the average of the specific field on the $n$th day for 41 OCS events. The $n$th day before (after) the occurrence of OCS event is recorded as time $=-n(+n)$ th day, and the day of the OCS occurrence is recorded as time $=0$ day. The anomalies presented in this study are computed as deviations from the daily climatological annual cycle during 1998-2013. A two-sided Student's $t$-test is used to assess statistical significance.

\section{Results and Discussion}

3.1. Dynamic Tropopause. Figure 2(a) shows the composite time series of anomalous dynamic tropopause height and tropopause temperature from the 15th day before to the 5th day after the OCS onset derived from ERA5 and ERA5.1 reanalysis data with the high resolution $\left(0.25^{\circ} \times 0.25^{\circ}\right)$ averaged for 41 OCS events. The dynamic tropopause height is estimated from the PV field using a 3.5 potential vorticity unit (PVU) threshold (1 PVU $\left.=10^{-6} \cdot \mathrm{m}^{2} \cdot \mathrm{K} \cdot \mathrm{kg}^{-1} \cdot \mathrm{s}^{-1}\right)$. It is evident that the tropopause height rises rapidly from the time $=-14$ th day to -11 th day. It then decreases slightly from the time $=-11$ th day to -10 th day. The tropopause height reaches the maximum height at the time $=-7$ th day and -5 th day. It then descends significantly from the time $=-5$ th day to -1 st day, followed by a small fluctuation in the tropopause height between the time $=-1$ st day and 0 day. The difference of
TABLE 1: The dates of the 41 OCS events during 1998-2013 over the TP.

\begin{tabular}{lc}
\hline Case & Date \\
\hline 1 & June $23,1998,08: 54 \mathrm{am}$ \\
2 & June 25, 1999, 10:04 am \\
3 & June 28, 1999, 12:53 pm \\
4 & August $14,1999,09: 25 \mathrm{am}$ \\
5 & August $14,1999,11: 01 \mathrm{am}$ \\
6 & June $17,2007,12: 54 \mathrm{pm}$ \\
7 & August $19,2008,12: 18 \mathrm{pm}$ \\
8 & August $19,2008,12: 19 \mathrm{pm}$ \\
9 & August $19,2008,01: 55 \mathrm{pm}$ \\
10 & July $19,2009,11: 10 \mathrm{am}$ \\
11 & July $20,2009,10: 15 \mathrm{am}$ \\
12 & July 20, 2009, 11:54 am \\
13 & July $21,2009,09: 21 \mathrm{am}$ \\
14 & August $06,2010,08: 56 \mathrm{am}$ \\
15 & August $09,2010,09: 23 \mathrm{am}$ \\
16 & August $09,2010,09: 24 \mathrm{am}$ \\
17 & August $10,2010,06: 52 \mathrm{am}$ \\
18 & August $10,2010,08: 28 \mathrm{am}$ \\
19 & August $10,2010,08: 30 \mathrm{am}$ \\
20 & August $10,2010,10: 06 \mathrm{am}$ \\
21 & August $12,2010,08: 15 \mathrm{am}$ \\
22 & August $12,2010,08: 16 \mathrm{am}$ \\
23 & August $12,2010,08: 17 \mathrm{am}$ \\
24 & August $13,2011,01: 32 \mathrm{pm}$ \\
25 & August $16,2011,10: 45 \mathrm{am}$ \\
26 & August $17,2011,09: 51 \mathrm{am}$ \\
27 & August $17,2011,11: 28 \mathrm{am}$ \\
28 & July $13,2012,09: 51 \mathrm{am}$ \\
29 & August $14,2012,04: 22 \mathrm{pm}$ \\
30 & June $15,2013,09: 11 \mathrm{am}$ \\
31 & June $17,2013,08: 57 \mathrm{am}$ \\
32 & July $12,2001,11: 16 \mathrm{am}$ \\
33 & July $15,2002,01: 12 \mathrm{pm}$ \\
34 & July $31,2003,11: 07 \mathrm{am}$ \\
35 & August $09,2003,09: 17 \mathrm{am}$ \\
36 & August $11,2003,09: 02 \mathrm{am}$ \\
37 & August $11,2003,09: 03 \mathrm{am}$ \\
38 & August $22,2004,10: 11 \mathrm{am}$ \\
39 & July $01,2005,03: 27 \mathrm{pm}$ \\
40 & July $19,2006,02: 48 \mathrm{pm}$ \\
\hline 1 & July $20,2006,03: 30 \mathrm{pm}$ \\
\hline &
\end{tabular}

tropopause height between the time $=-5$ th day and the time $=-1$ st day can reach $0.21 \mathrm{~km}$. The tropopause height ascends after the OCS onset. The variation of tropopause temperature is consistent with the tropopause height, except that the tropopause temperature is abnormally high on the day of OCS onset. Figure 2(b) shows the composite evolution of time-pressure cross sections of vertical velocity from the 15th day before to the 5th day after the onsets of OCS averaged for 41 OCS events. Note that there are weak descending motions in the lower stratosphere and upper troposphere when the weak descending of tropopause height occurs near the time $=-9$ th day. From the time $=-6$ th day to -1 st day, the ascending motions are found at $500-150 \mathrm{hPa}$ in the troposphere. At the time $=-5$ th day, the upward motion in the troposphere is the strongest, which can reach near the tropopause when the maximum positive anomaly of 


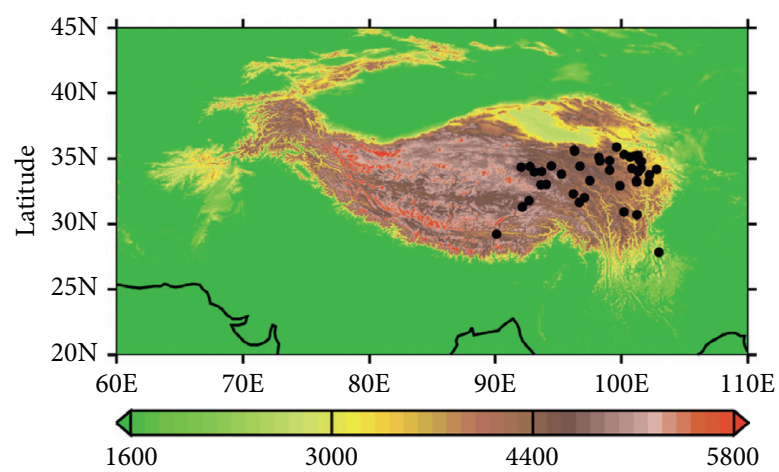

(a)

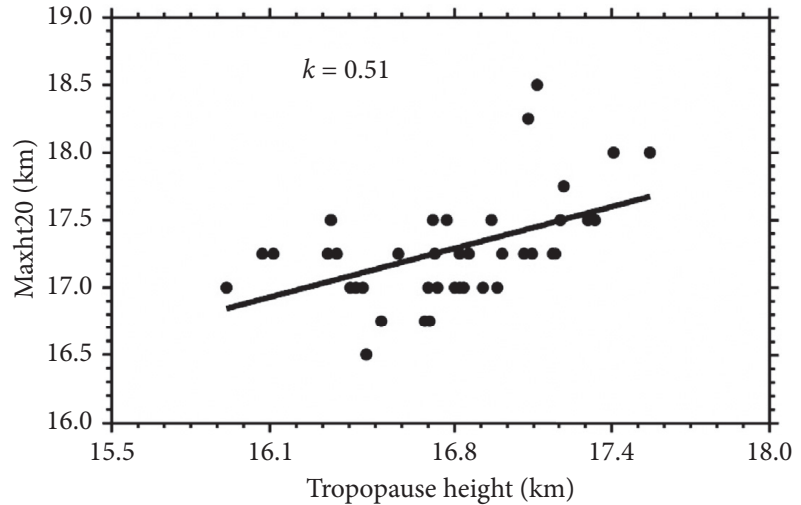

(b)

Figure 1: (a) The spatial distribution of topography (units: m). The black dots indicate geographical locations of the 41 OCS events in summer derived TRMM PFs with $20 \mathrm{dBZ}$ echo tops reaching above the lapse rate tropopause during 1998-2013 over the TP. (b) Scatter plot of Maxht20 (units: km) and tropopause height (units: km) above sea level derived from 41 OCS events.

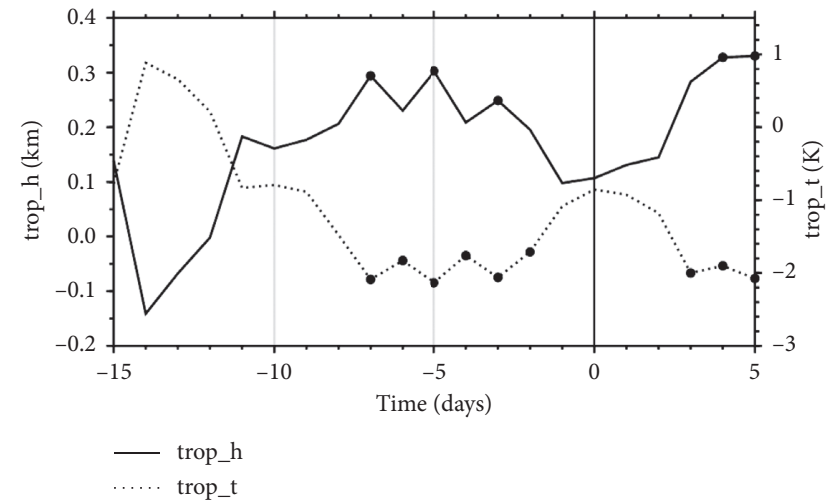

(a)

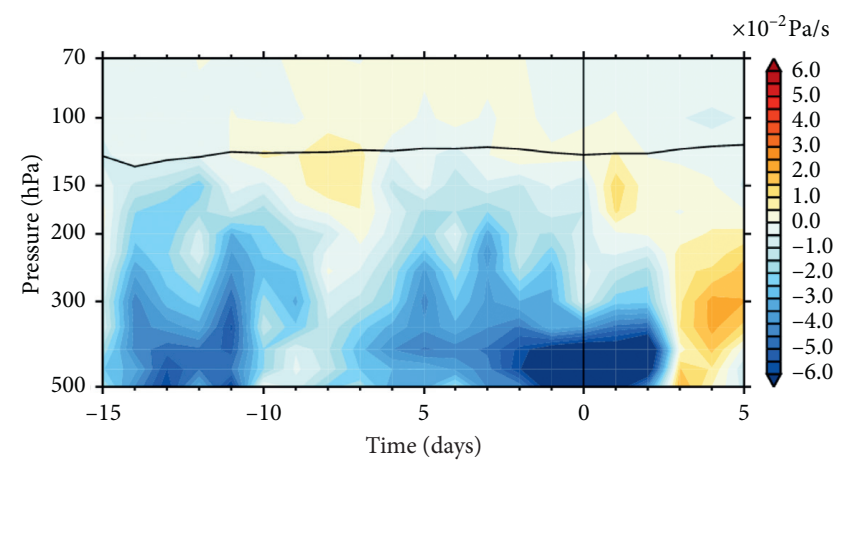

(b)

Figure 2: (a) The composite daily time series of anomalous tropopause height (units: km, solid line) and tropopause temperature (units: K, dotted line) from the 15th day before to the 5th day after the onsets of OCS for 41 OCS events. Black dots indicate that the anomalies are statistically significant at a 95\% confidence level (based on a two-sided Student's $t$-test). (b) Composites of time-pressure cross section of the vertical velocity (units: $10^{-2} \mathrm{~Pa} / \mathrm{s}$ ) from the 15 th day before to the 5th day after the OCS onset for 41 OCS events. The horizontal black solid line represents the tropopause height; the vertical black solid line indicates the day of the OCS onset.

tropopause height occurs, corresponding to highest tropopause height. From the time $=-1$ st day to 1st day, there are strong ascending motions at $500-300 \mathrm{hPa}$ but weak descending motions near the tropopause (Figure 2(b)). We can note that the change in tropopause height accompanying OCS is closely related with the evolution of vertical velocity, and the overshooting convection does not occur when the upward motion in the upper troposphere is strong due to the higher tropopause height at the time $=-5$ th day. However, the overshooting convection occurs when the tropopause height is lowered at the time $=0$ day.

To show the details of anomalous tropopause height pattern before the onsets of the OCS events, the composite horizontal distributions of tropopause height anomalies at the time $=-7$ th, -6 th, -5 th, -4 th, $-3 \mathrm{rd},-2 \mathrm{nd},-1 \mathrm{st}$, and 0 day for 41 OCS events are shown in Figure 3. Note that significant variation of the tropopause height before the onsets of the OCS events occurs over the eastern TP. The tropopause height over the eastern TP is significantly strong positive anomaly from the time $=-7$ th day to -4 th day (Figures 3(a)-3(d)). The positive anomaly of tropopause height over the east of TP slightly decreases from the time $=-3$ rd day to -2 nd day (Figures $3(e)-3(f)$ ). At the time $=-1$ st day and 0 day, the tropopause height becomes significantly negative anomaly at the longitude range of $96^{\circ}-100^{\circ} \mathrm{E}$ (Figures $3(\mathrm{~g})-3(\mathrm{~h})$ ). This is consistent with the descending of tropopause height between the time $=-1$ st day and 0 day shown in Figure 2(a). Chen et al. [28] indicated that the interaction occurred between deep convective boundary layer and the low tropopause over the TP, 


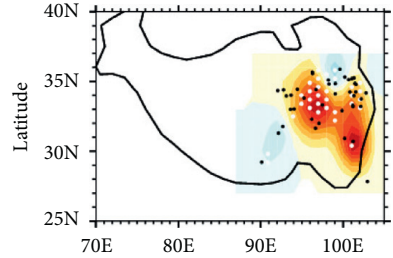

(a)

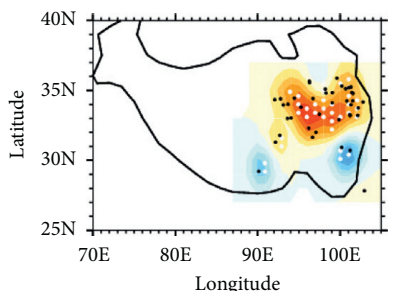

(e)

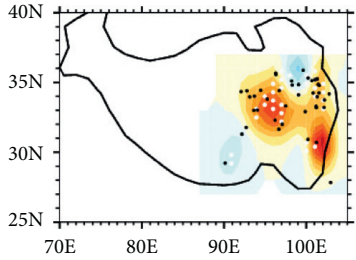

(b)

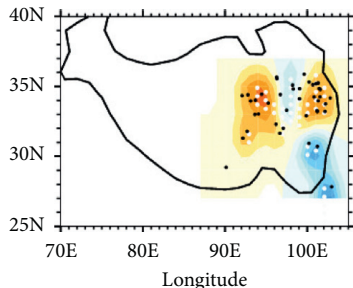

(f)

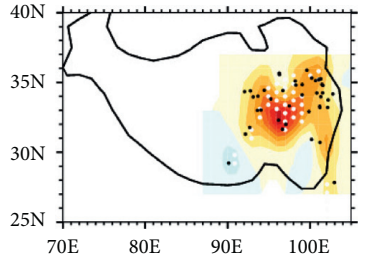

(c)

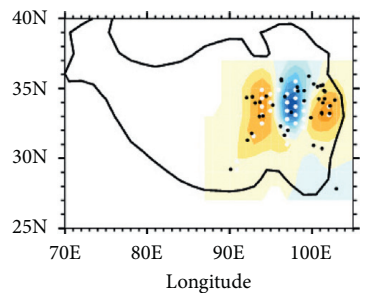

(g)

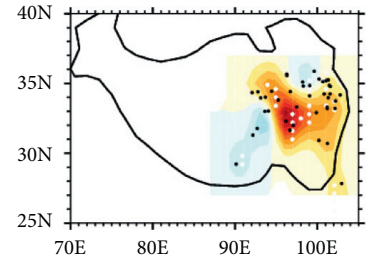

(d)

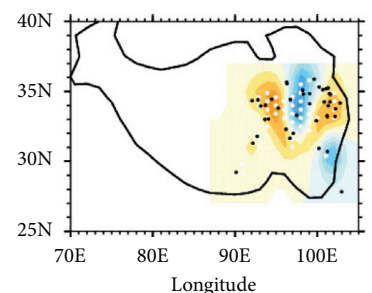

(h)

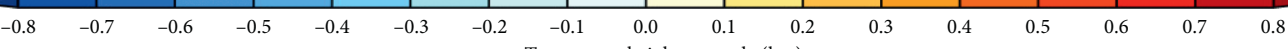

Tropopause height anomaly $(\mathrm{km})$

Figure 3: The composite horizontal distributions of anomalous tropopause height (units: $\mathrm{km}$ ) for the (a) 7th day, (b) 6th day, (c) 5th day, (d) 4th day, (e) 3rd day, (f) 2nd day, (g) 1st day, and (h) 0 day before the OCS onset for 41 OCS events. The white dotted areas indicate that the anomalies are statistically significant at a $95 \%$ confidence level (based on a two-sided Student's $t$-test). The black dots indicate the locations of the 41 OCS events.

and convection was a central player in cases of the high convective boundary layer. Griffiths et al. [31] also proposed that there is a dynamical link between the lowered tropopause and convection. Therefore, the decrease of the tropopause height at the time $=-1$ st day and 0 day may be related to the occurrence of OCS. Chen et al. [58] demonstrated that variations in the height of the tropopause were related to tropopause folds. It is likely that the decrease in tropopause height at the time $=-1$ st day and 0 day in Figures 2(a) and 3 results from a tropopause fold event. In the next section, the characteristics of tropopause fold are analyzed.

3.2. Potential Vorticity. The dynamical role of the tropopause can be determined using the PV concepts. In order to understand the possible mechanism of descending of tropopause height accompanying the OCS events, Figure 4 shows the composite horizontal distribution of PV anomalies on $350 \mathrm{~K}$ isentropic surface at the time $=-7 \mathrm{th},-6 \mathrm{th}$, -5 th, -4 th, $-3 \mathrm{rd},-2 \mathrm{nd},-1 \mathrm{st}$, and 0 day. From the time $=-7$ th day to -4 th day before the OCS onset, large negative anomalies of $\mathrm{PV}$ on $350 \mathrm{~K}$ isentropic surface are found over the eastern TP (Figures 4(a)-4(d)), which are consistent with the strong positive anomalies of the tropopause height (Figures 4(a)-4(d)). The lower PV in the upper troposphere suggests upward transport of air mass over the eastern TP. After the time $=-3$ rd day, the negative anomalies of PV on $350 \mathrm{~K}$ isentropic surface gradually weaken (Figures $4(\mathrm{e})$ and $4(\mathrm{f})$ ), and the PV values on $350 \mathrm{~K}$ isentropic surface become strong positive anomaly at $96^{\circ}-100^{\circ} \mathrm{E}$ at the time $=-1$ st day and 0 day (Figures $4(\mathrm{~g})$ and $4(\mathrm{~h})$ ). The positive $\mathrm{PV}$ anomalies on $350 \mathrm{~K}$ isentropic surface at $96^{\circ}-100^{\circ} \mathrm{E}$ in Figures $4(\mathrm{~g})$ and $4(\mathrm{~h})$ are related with the descending of tropopause height shown in Figures $3(\mathrm{~g})$ and 3(h). It is possible that stratospheric air with higher PV values invades into the troposphere and accumulates, leading to a decrease in the tropopause height. This is in agreement with mechanisms proposed by Chen et al. [28].

The composites of longitude-pressure cross sections at $34^{\circ} \mathrm{N}$ and latitude-pressure cross section at $98^{\circ} \mathrm{E}$ of $\mathrm{PV}$ and potential temperature at the time $=-7 \mathrm{th},-6 \mathrm{th},-5 \mathrm{th},-4 \mathrm{th}$, $-3 \mathrm{rd},-2 \mathrm{nd},-1 \mathrm{st}$, and 0 day for 41 OCS events are shown in Figure 5. Previous studies have shown that the PV values ranging from 1 to $3 \mathrm{PVU}$ can qualitatively delineate the tropopause location based on sounding and aircraft data $[59,60]$. From the time $=-7$ th day to -2 nd day, the PV is higher in the stratosphere and lower in the troposphere, and the change of the tropopause height is very little (Figures 5(a)-5(f)). It is worth noting that there is tropopause depression, and a high PV center (1.5-2.0 PVU) near the $300-200 \mathrm{hPa}$ locates at around $96^{\circ}-99^{\circ} \mathrm{E}$ at the time $=-1$ st day (Figure $5(\mathrm{~g})$ ). The tropopause fold structure is evident at the time $=0$ day, with the tongue of the tropopause fold located at $96^{\circ}-99^{\circ} \mathrm{E}$, and the stratospheric air with higher $\mathrm{PV}$ values extends deep into the troposphere at a height of about $300 \mathrm{hPa}$ (Figure 5(h)). From Figures 5(g1)-5(h1), the dynamical tropopause also exhibits a folded structure at $32.5^{\circ}-34^{\circ} \mathrm{N}$. These results are consistent with the distribution of tropopause height displayed in Figure 2(a), which show that the tropopause height reaches its minimum value at the time $=-1$ st day and 0 day. Figures 4 and 5 suggest that a tropopause fold event does indeed occur at $96^{\circ}-99^{\circ} \mathrm{E}$ at the time $=-1$ th day and 0 day, and the descending of the tropopause height accompanying OCS onset at $96^{\circ}-99^{\circ} \mathrm{E}$ is caused by tropopause fold events.

Previous studies have shown that the tropopause fold with a medium intensity occurs frequently over the TP in the summer with a high value center located near $92^{\circ}-97^{\circ} \mathrm{E}$ over the eastern TP [61]. Due to the high occurrence frequency of 


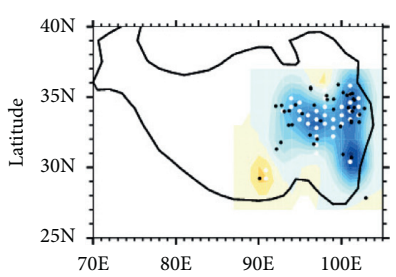

(a)

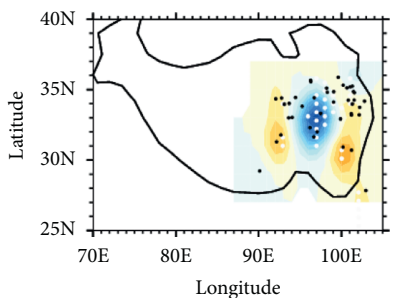

(e)

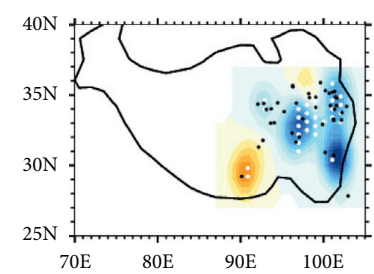

(b)

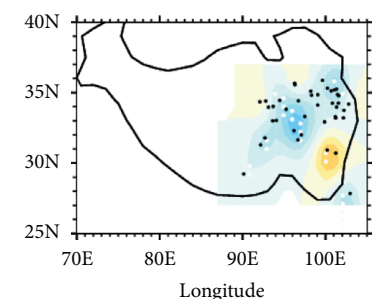

(f)

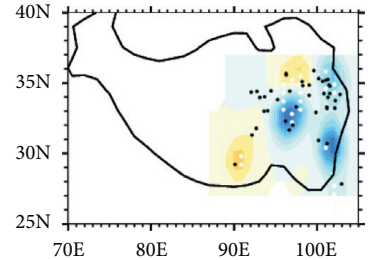

(c)

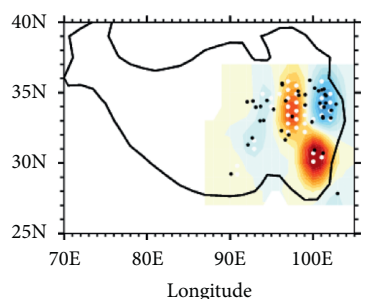

(g)

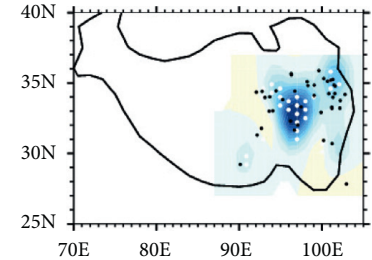

(d)

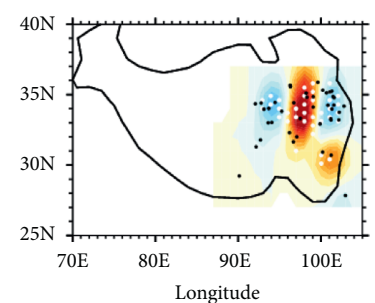

(h)

$\begin{array}{lllllllllllllllllllll}-0.60 & -0.54 & -0.48 & -0.42 & -0.36 & -0.30 & -0.24 & -0.18 & -0.12 & -0.06 & -0.00 & 0.06 & 0.12 & 0.18 & 0.24 & 0.30 & 0.36 & 0.42 & 0.48 & 0.54 & 0.60\end{array}$

PV anomaly (PVU)

FIgURE 4: The composite horizontal distributions of anomalous PV (units: PVU) on $350 \mathrm{~K}$ isentropic surface for the (a) 7th day, (b) 6th day, (c) 5th day, (d) 4th day, (e) 3rd day, (f) 2nd day, (g) 1st day, and (h) 0 day before the OCS onset for 41 OCS events. The white dotted areas indicate that the anomalies are statistically significant at a $95 \%$ confidence level (based on a two-sided Student's $t$-test). The black dots indicate the locations of the 41 OCS events.

the tropopause fold, stratospheric intrusion should frequently happen over the eastern TP, which makes important contributions to downward transport of the stratospheric air with higher PV to the troposphere [62-70]. Figures 4 and 5 suggest that a tropopause fold event does indeed occur over the eastern TP and results in obvious upper-level PV anomaly at the time $=-1$ st day and 0 day. Hoskins et al. [71] and Russell et al. [72] proposed that upper-level PV anomalies can reduce convective stability in the troposphere. From Figure 1(a), we can see that the overshooting convective systems in this study also occur mainly over the eastern TP. This intrusion of high PV air may be the result of the latent-heat release at the time $=0$ day. It is possible that the descending of the tropopause height caused by frequent tropopause fold events over the eastern TP at the time $=0$ day is beneficial to the occurrence of OCS.

3.3. Wind Fields. An analysis of the geopotential height fields and wind fields at dynamic tropopause height (3.5 PVU surface) at the time $=-5$ th,-4 th, -3 rd,-2 nd, -1 st and 0 day (Figure 6) reveals that the tropopause fold event is associated with a cold air trough over the east of the TP, with its western flank extending southeastward into the south of the TP at the time $=-4$ th day (Figure. 6(b)). This low pressure trough moves southeastward and deepens, forming a low pressure center at around $\left(25^{\circ} \mathrm{N}, 105^{\circ} \mathrm{E}\right)$ at the time $=-2$ nd day (Figure 6(d)). From the time $=-1$ st day to 0 day, the low pressure center disappears and the low pressure trough becomes east-west, and a high pressure ridge locates over the eastern TP (Figures 6(e) and 6(f)). The composited zonal wind speed fields indicate that an upper-level westerly jet stream at 3.5 PVU surface develops at the time $=-5$ th day (Figure 6(a)) and enhances with a jet stream center located over the northern TP at the time $=-4$ th day $($ Figure 6(b)). In accordance with the movement of the pressure trough, the westerly jet stream intensifies and moves eastward to the northeastern TP from the time $=-3$ rd day to 0 day (Figures 6(c)-6(f)). At the same time, the anticyclone circulation over the western TP also moves eastward from the time $=-5$ th day to -1 st day (Figures $6(\mathrm{a})-6(\mathrm{e}))$. On the day of OCS onset, the anticyclone circulation center moves to the eastern TP (Figure. 6(f)). It is apparent that the upper-level jet stream, a typical synoptic system related to the formation of the tropopause fold event, is forced by the geostrophic adjustment process associated with the cold air trough. Previous studies have shown that in order to maintain the heat-forming balance, a secondary circulation will be triggered in the vicinity of the upper-level jet stream so that the tropopause is folded downward along the sinking branch of the secondary circulation $[73,74]$. This is one of the main mechanisms for the formation of the tropopause fold.

Figure 7 shows the horizontal distribution of vertical velocity on $350 \mathrm{~K}$ isentropic surface from the 7 th day to 0 day before the OCS onset for 41 OCS events. Note that the ascending motion on $350 \mathrm{~K}$ surface is the strongest at the time $=-5$ th day (Figure $7(\mathrm{c})$ ), resulting in the highest tropopause height shown in Figure 2(a). It is apparent from Figure $7(\mathrm{~h})$ that the area where the tropopause fold is located is accompanied by weak ascending motion at $95^{\circ}-98^{\circ} \mathrm{E}$, while the sinking motion is located to the east of $98^{\circ} \mathrm{E}$ at the time $=0$ day. The most striking feature in Figures $8(\mathrm{e})-8(\mathrm{~h})$ is that the vertical velocity on $350 \mathrm{~K}$ isentropic surface appears alternately between the positive and negative centers from the time $=-3$ rd day to 0 day. Previous study found that the forcing terms of the omega and geopotential tendency equation mark the genesis of the extratropical cyclones on the storm track, and they have a maximum value on the lee 


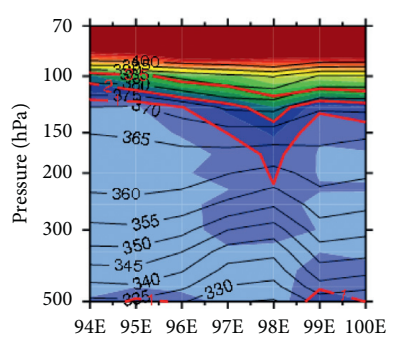

(a)

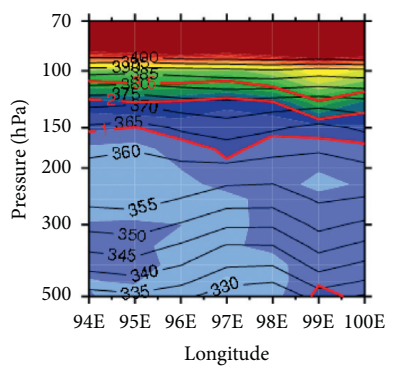

(e)

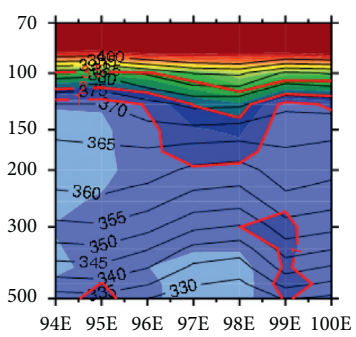

(b)

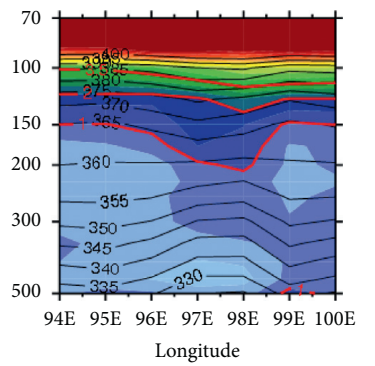

(f)

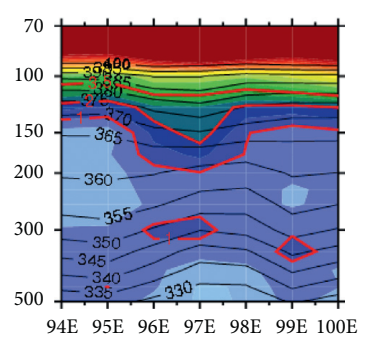

(c)

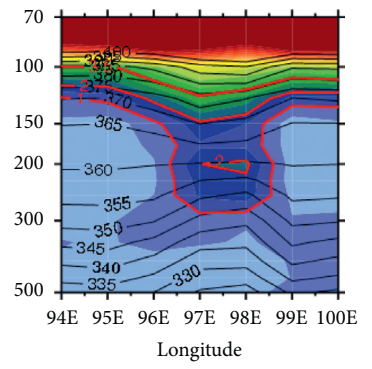

(g)

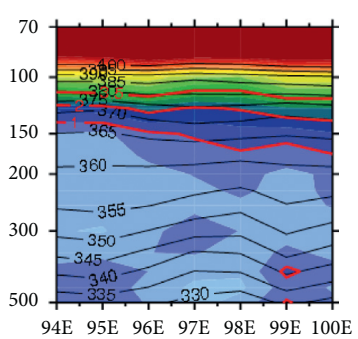

(d)

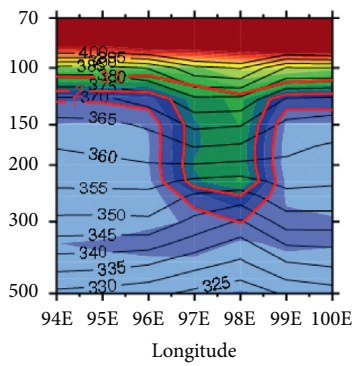

(h)
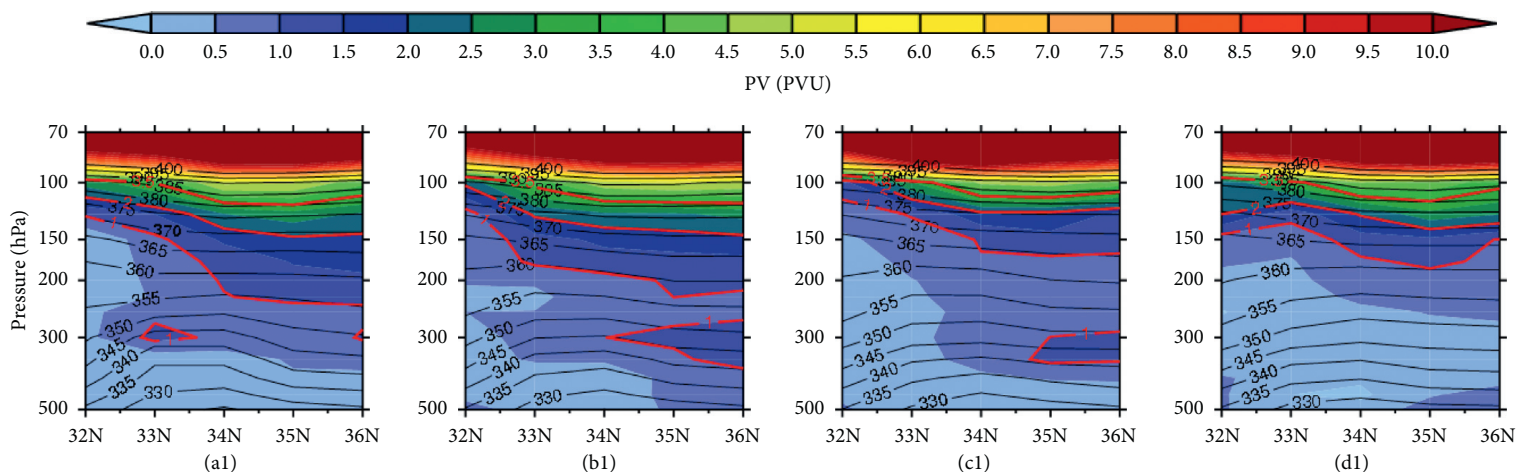

(d1)
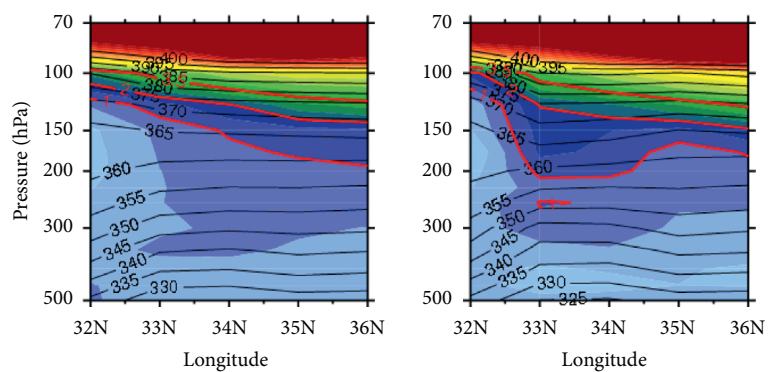

(c1)

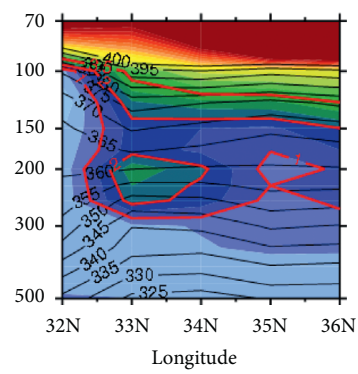

(g1)

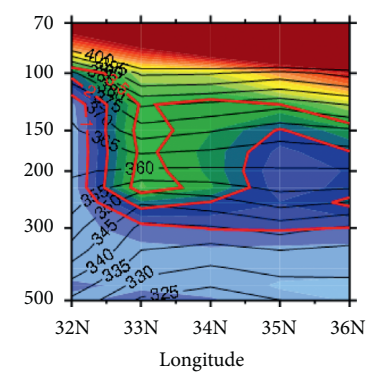

(h1)

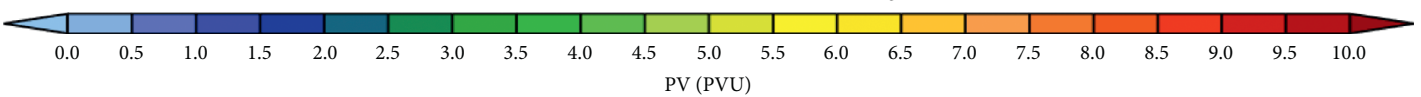

Figure 5: The composites of (a-h) longitude-pressure cross section at $34^{\circ} \mathrm{N}$ and (a1-h1) latitude-pressure cross section at $98^{\circ} \mathrm{E}$ of $\mathrm{PV}$ (units: PVU, color contours) and potential temperature (units: K, black lines, contour interval: $5 \mathrm{~K}$ ) fields for the (a, a1) 7th day, (b, b1) 6th day, (c, c1) 5th day, (d, d1) 4th day, (e, e1) 3rd day, (f, f1) 2nd day, (g, g1) 1st day, and (h, h1) 0 day before the OCS onset for 41 OCS events. The red lines show the contours of 1,2 , and 3.5 PV units.

side of the TP [34]. It also corresponds to a region of baroclinic development [34]. So the upward movements are intensified through baroclinic processes in this region.

Figure 8 shows the composites of longitude-pressure cross sections of vertical velocity and potential temperature at $34^{\circ} \mathrm{N}$ at the 7 th, 6 th, 5 th, 4 th, $3 \mathrm{rd}, 2 \mathrm{nd}, 1$ st, and 0 day before the OCS onset for OCS events. From the time $=-3$ rd day to -2 nd day, there are weak ascending motions at $96^{\circ}-98.5^{\circ} \mathrm{E}$ and descending motions to the west of $96^{\circ} \mathrm{E}$ and east of $98.5^{\circ} \mathrm{E}$ in the troposphere (Figures 9(e) and 9(f)). These ascending motions at $96^{\circ}-98.5^{\circ} \mathrm{E}$ and descending motions in the troposphere enhance at the time $=-1$ st day (Figure $8(\mathrm{~g})$ ). With the deepening of the tropopause fold, the area behind the fold at around $94^{\circ}-97.5^{\circ} \mathrm{E}$ is accompanied by significant downward motion near tropopause, while the area beneath the fold in the troposphere at $96^{\circ}-98.5^{\circ} \mathrm{E}$ is marked by prevailing upward motion at $500-250 \mathrm{hPa}$ at the time $=0$ day (Figure $8(\mathrm{~h}))$. That is, when a strong tropopause 


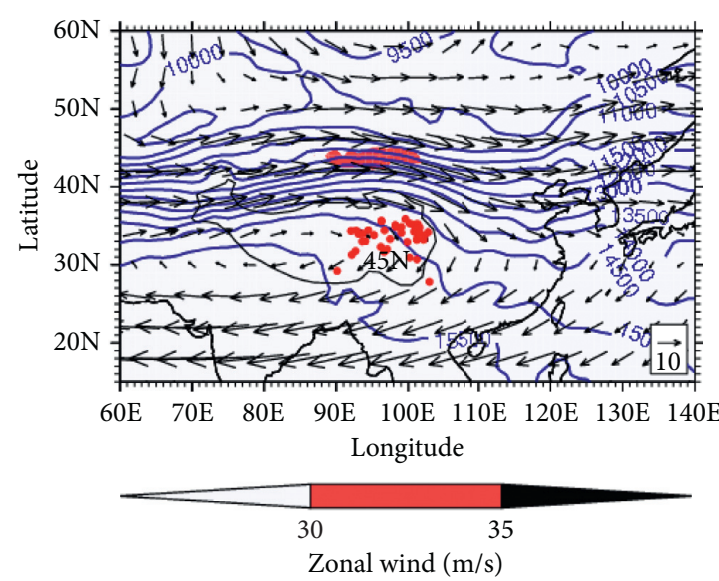

(a)

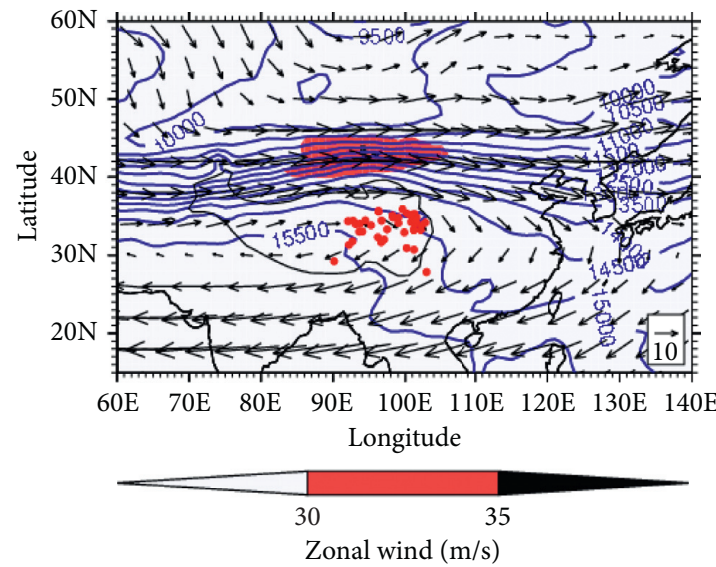

(c)

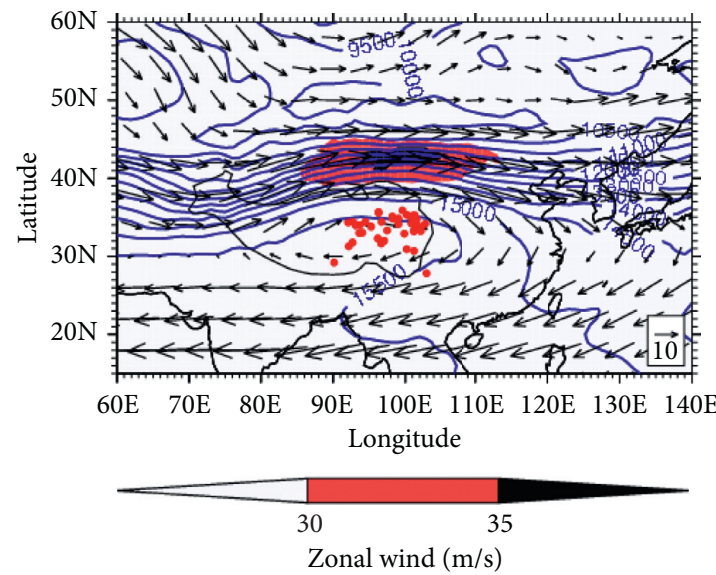

(e)

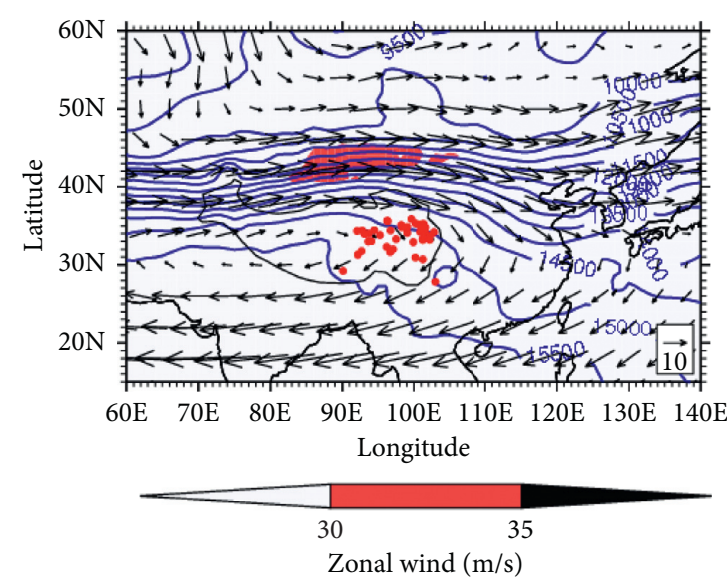

(b)

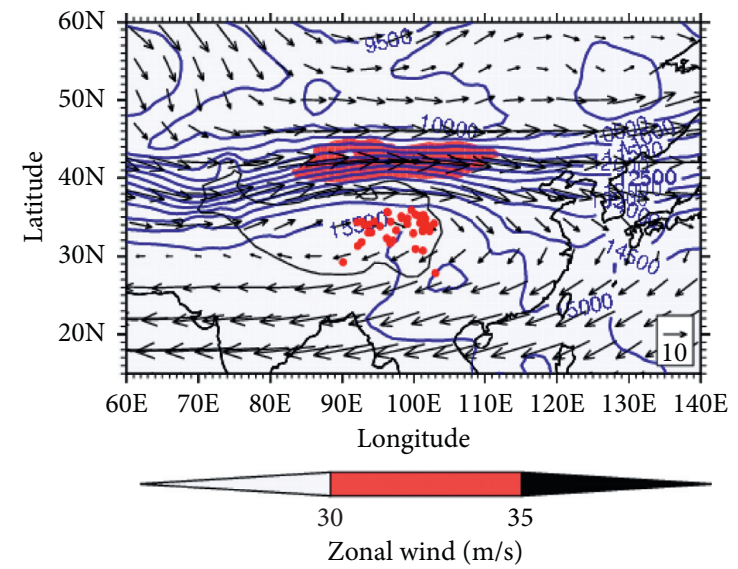

(d)
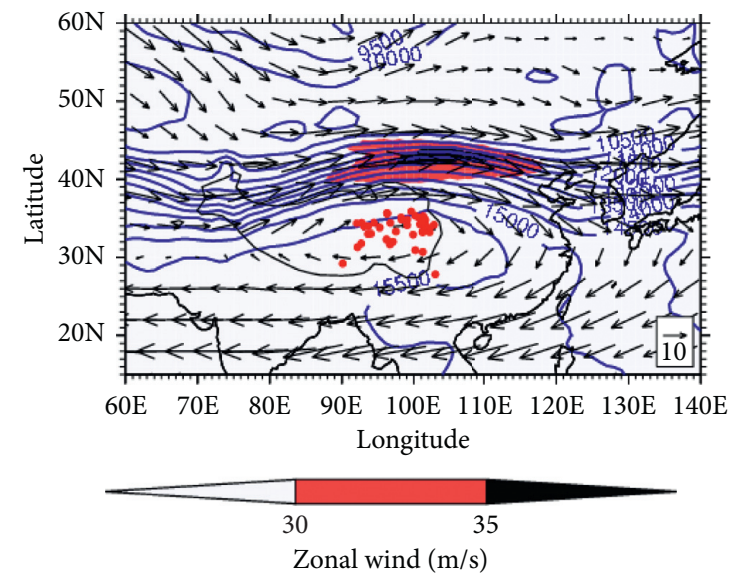

(f)

Figure 6: The composites of geopotential height (units: gpm, blue lines) and wind fields (black arrow, and color contours indicate the areas where the zonal wind speed is greater than $30 \mathrm{~m} / \mathrm{s}$ ) on the dynamic tropopause height (3.5 PVU) for the (a) 5th day, (b) 4th day, (c) 3rd day, (d) 2 nd day, (e) 1st day, and (f) 0 day before the OCS onset for 41 OCS. The red dots indicate the locations of the 41 OCS events.

fold event occurs, there is not only strong downward transport of air mass from the stratosphere, but also ascending motion in the troposphere beneath the folding region. Moreover, the upward curvature of the isentropic surface in the troposphere associated with a PV anomaly can be seen clearly in the region beneath the tropopause fold from the time $=-1$ st day to 0 day (Figures $8(\mathrm{~g})-9(\mathrm{~h}))$. The upward and downward displacements of isentropic surfaces are associated with ascent of tropospheric air beneath the depressed tropopause and descent of air at both sides of the depressed tropopause between the time $=-1$ st day and 0 day. This ascent can contribute to the development of deep 


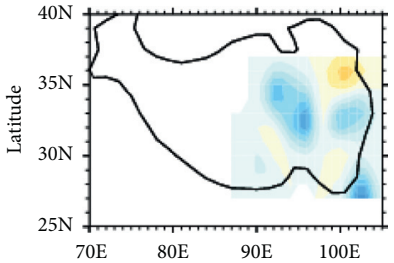

(a)

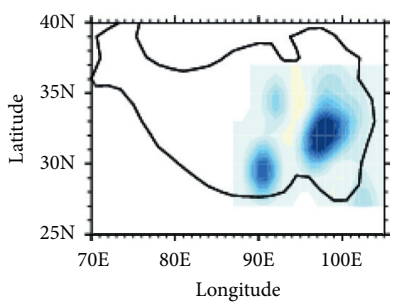

(e)

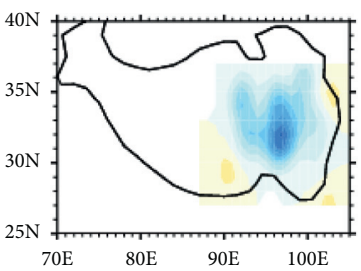

(b)

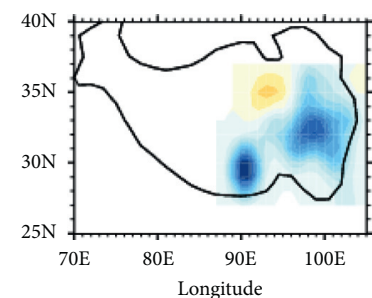

(f)

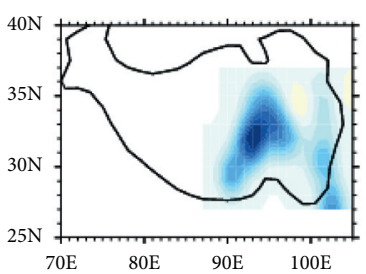

(c)

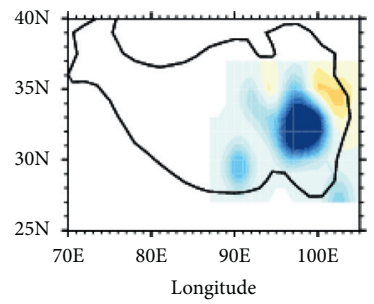

(g)

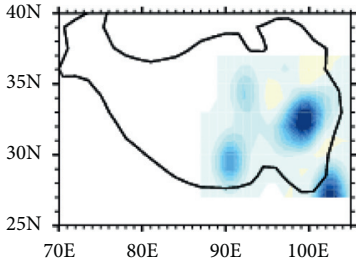

(d)

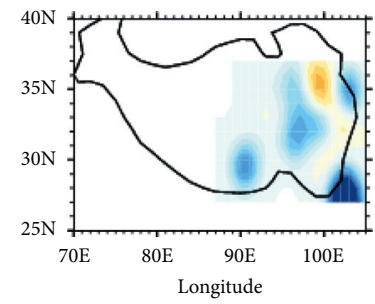

(h)

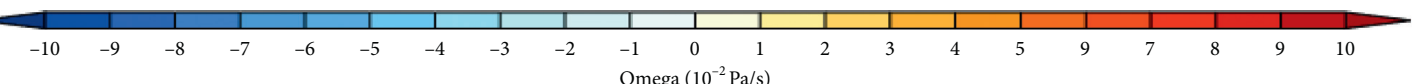

FIgURE 7: The composite horizontal distributions of vertical velocity (units: $10^{-2} \mathrm{~Pa} / \mathrm{s}$ ) on $350 \mathrm{~K}$ isentropic surface for the (a) 7 th day, (b) 6th day, (c) 5th day, (d) 4th day, (e) 3rd day, (f) 2nd day, (g) 1st day, and (h) 0 day before the OCS onset for 41 OCS events.

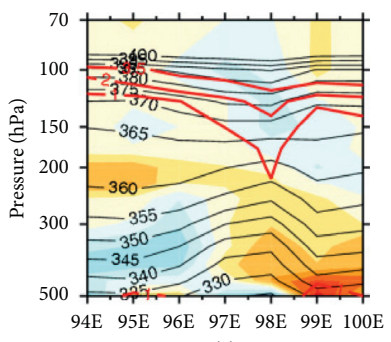

(a)

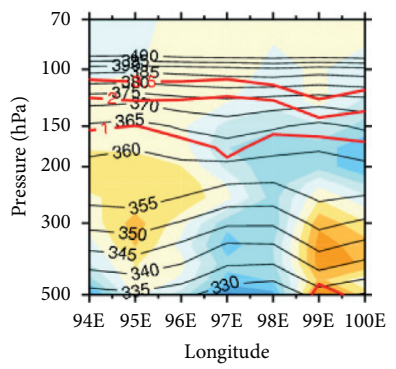

(e)

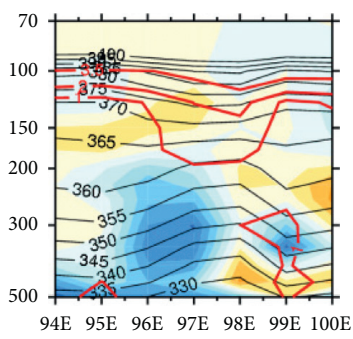

(b)

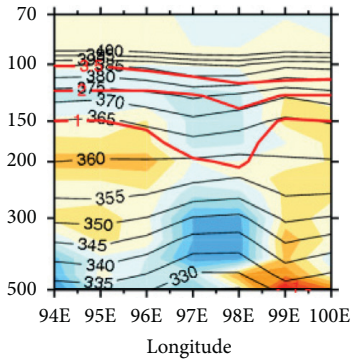

(f)

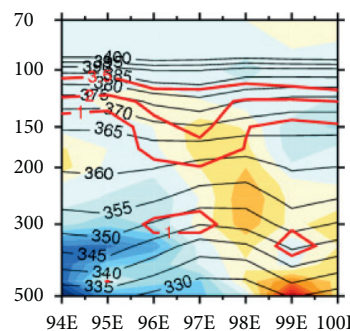

(c)

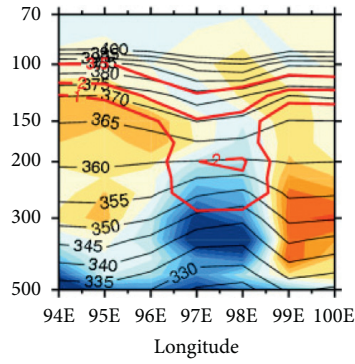

(g)

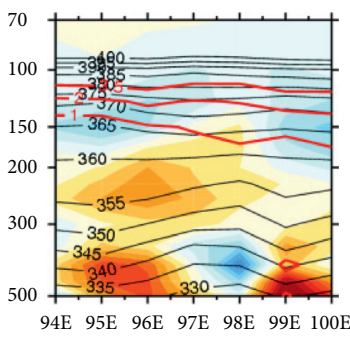

(d)

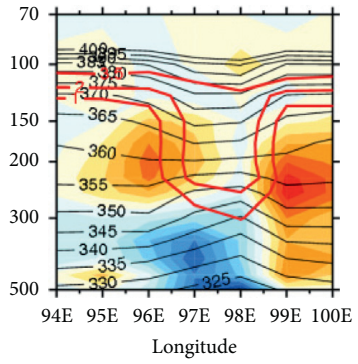

(h)

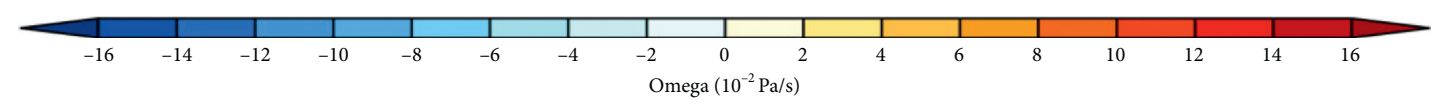

Figure 8: The composites of longitude-pressure cross section of vertical velocity (units: $10^{-2} \mathrm{~Pa} / \mathrm{s}$, color contours) and potential temperature (units: K, black lines, contour interval: $5 \mathrm{~K}$ ) fields at $34^{\circ} \mathrm{N}$ for the (a) 7 th day, (b) 6 th day, (c) 5 th day, (d) 4 th day, (e) 3 rd day, (f) 2 nd day, (g) 1 st day, and (h) 0 day before the OCS onset for 41 OCS events. The red lines show the contours of 1,2 , and 3.5 PV units.

convection by releasing potential instability [75]. We can see that the overshooting convection is more likely to occur due to the lower tropopause height, although the upward motion in the troposphere is not the strongest at the time $=0$ day.

3.4. Static Stability. The vertical changes of temperature will lead to changes in static stability [76]. Figure 9 shows the composites of longitude-pressure cross sections of temperature and static stability anomaly at $34^{\circ} \mathrm{N}$ for the $3 \mathrm{rd}, 2 \mathrm{nd}$, 1st, and 0 day before the OCS onset for OCS events. It is clear that the temperature near the tropopause is a negative anomaly, and the temperature at $700-250 \mathrm{hPa}$ is a positive anomaly at the time $=-3$ rd day (Figure 9(a)), the corresponding static stability in the upper troposphere is weakened (Figure $9(\mathrm{e})$ ). From the time $=-1$ st day to 0 day, the positive anomaly of temperature occurs above the depressed tropopause in the lower stratosphere at around $96.5^{\circ}-99^{\circ} \mathrm{E}$, and the negative anomaly of temperature is strengthened to the west of $96.5^{\circ} \mathrm{E}$ and the east of $99^{\circ} \mathrm{E}$ in the lower 


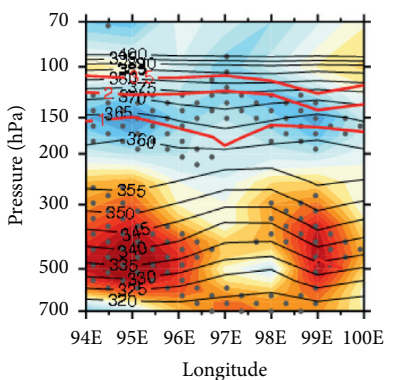

(a)

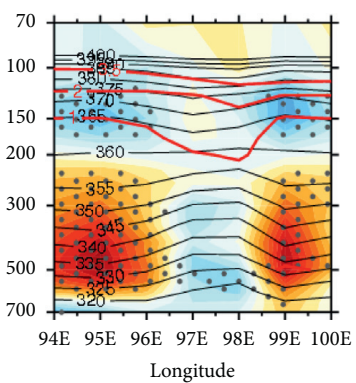

(b)

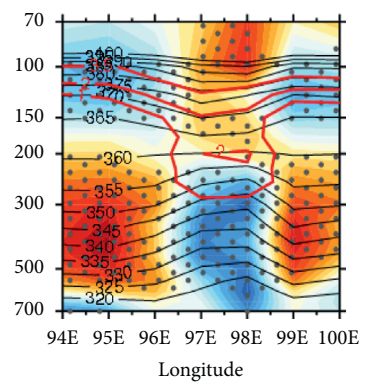

(c)

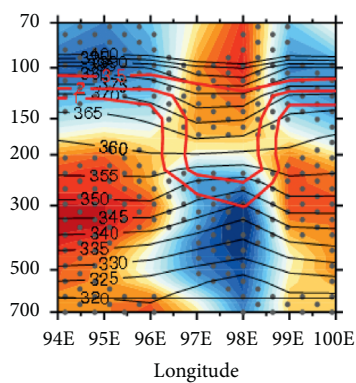

(d)

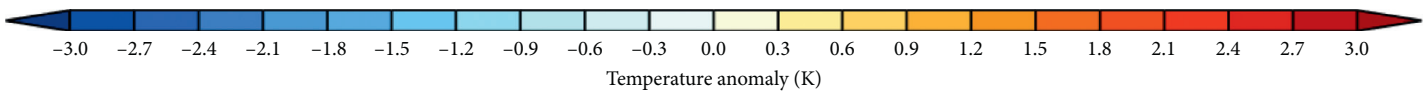

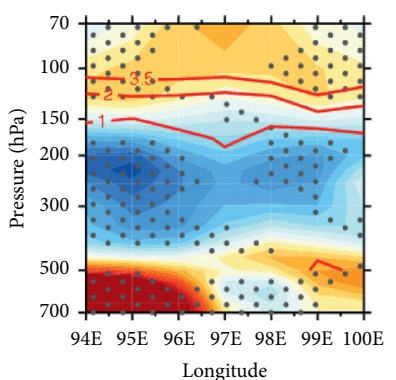

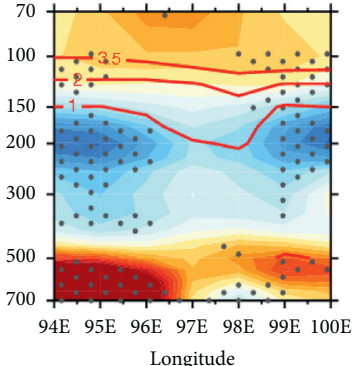

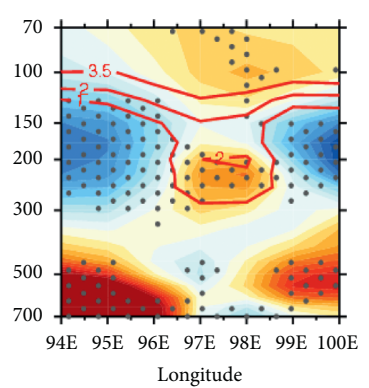

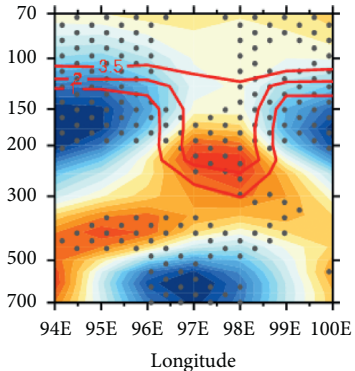

(h)

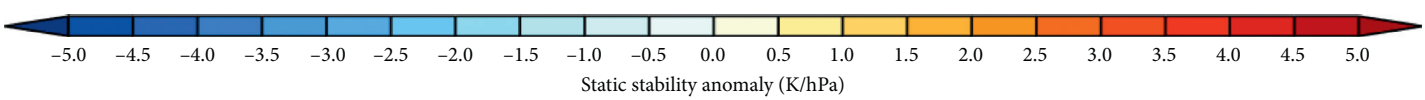

Figure 9: The composites of longitude-pressure cross section of ( $a, b, c, d$ ) temperature anomaly (units: K, color contours) and potential temperature (units: $\mathrm{K}$, black lines, contour interval: $5 \mathrm{~K}$ ), and (e, $\mathrm{f}, \mathrm{g}, \mathrm{h}$ ) static stability anomaly (units: $\mathrm{K} / \mathrm{hPa}$ ) at $34^{\circ} \mathrm{N}$ for the (a, e) $3 \mathrm{rd}$ day, $(\mathrm{b}, \mathrm{f}) 2$ nd day, (c, g) 1st day, and (d, h) 0 day before the OCS onset for 41 OCS events. The black dotted areas indicate that the anomalies are statistically significant at a 95\% confidence level (based on a two-sided Student's $t$-test). The red lines show the contours of 1, 2, and 3.5 PV units.

stratosphere (Figures 9(c) and 9(d)). At the same time, the temperature decreases below the depressed tropopause in the troposphere at around $96.5^{\circ}-98.5^{\circ} \mathrm{E}$ between the time $=-1$ st day and 0 day, and the strong positive temperature anomalies to the west of $96^{\circ} \mathrm{E}$ and the east of $99^{\circ} \mathrm{E}$ in the troposphere are related to the downward movement (Figures 9(c) and 9(d)). The temperature changes on both sides of the depressed tropopause in the lower stratosphere and upper troposphere are more intense at the time $=0$ day than that at the time $=-1$ st day. The strong horizontal temperature gradient near the tropopause tends to give rise to tropopause deformation or vertical discontinuity in the thermal tropopause on the day of OCS onset. The increase of temperature in the lower stratosphere at around $96.5^{\circ}-99^{\circ} \mathrm{E}$ tends to form a stable layer within the area of tropopause fold, while the decrease of temperature in the troposphere can lead to the decrease of static stability below the depressed tropopause at $700-500 \mathrm{hPa}$ at the time $=0$ day (Figure $9(\mathrm{~h})$ ). The change of temperature in the upper troposphere is consistent with the change of isentropic surfaces. Negative temperature anomalies appear in the region where the upward curvature of isentropic surfaces is located. The results shown in Figures 9(d) and 9(h) are consistent with the study from Morcrette et al. [77] that the upward displacement of isentropic surfaces can lead to an upper-level cold pool, which subsequently causes a reduction in static stability beneath the PV anomaly. This, under suitable conditions, will promote deep convection. Therefore, the upperlevel PV anomalies and their associated strong instability in the middle troposphere can trigger convective activities at the time $=0$ day.

\section{Conclusions}

Based on the TRMM and 6-hourly ERA5 and ERA5.1 datasets, this study implements the composite approach to analyze anomalous signals near the tropopause before the OCS onset over the TP. Based on the TRMM data, 41 OCS events over the TP are identified. Using the high-resolution ERA5 and ERA5.1 reanalysis datasets, the tropopause height is stable at the maximum height at the 7 th and 5th day before the OCS onset. It then descends significantly from the time $=-5$ th day to -1 st day. One day before and on the day of the OCS onset, the tropopause height is obviously decreased, corresponding to the increase of the tropopause temperature. At the time $=-5$ th day, the upward motion in the troposphere is the strongest, corresponding to highest tropopause height. From the time $=-1$ st day to 1 st day, there are strong ascending motions at $500-300 \mathrm{hPa}$ but weak descending motions near the tropopause. The change in 
tropopause height accompanying OCS is closely related with the evolution of vertical velocity. It is possible that the decreasing of the tropopause height one day before and on the day of OCS onset is beneficial to the occurrence of OCS.

It is proposed that the decreasing of the tropopause height on the day of OCS onset is associated with frequent tropopause fold events over the eastern TP. Analysis of ERA5 and ERA5.1 reanalysis data reveals that the tropopause fold events are caused by a cold trough intrusion from the north and the southeastward movement of upperlevel westerly jet stream. The positive PV anomalies on $350 \mathrm{~K}$ isentropic surface at $96^{\circ}-99^{\circ} \mathrm{E}$ can be noted in the descending region of the tropopause height at the time $=-1$ st day and 0 day. It is possible that the stratospheric air with higher PV values invades into the troposphere and accumulates as the decreasing of the tropopause height. With the deepening of the tropopause fold, the area behind the fold is accompanied by significant downward motion near the tropopause at around $94^{\circ}-97.5^{\circ} \mathrm{E}$, while the area beneath the fold in the troposphere is marked by prevailing upward motion at $500-300 \mathrm{hPa}$ at $96^{\circ}-98.5^{\circ} \mathrm{E}$ on the day of OCS onset. That is, when a strong tropopause fold event occurs, there is not only strong downward transport of air mass from the stratosphere, but also upward motion in the troposphere beneath the folding region. The vertical velocity near the depressed tropopause appears alternately between the positive and negative centers from the time $=-3$ rd day to 0 day, which is related to the baroclinic processes. Furthermore, the upward displacement of isentropic surfaces leads to an upper-level cold pool, which causes a reduction in static stability beneath the PV anomaly on the day of OCS onset. The upper-level PV anomalies and their associated strong instability in the midtroposphere can trigger convective activities by releasing potential instability on the day of the OCS onset. The overshooting convection is more likely to occur due to lower tropopause height, although the upward motion in the troposphere is not the strongest.

\section{Data Availability}

The ERA5 reanalysis data used to support the findings of this study are available at https://www.ecmwf.int/en/forecasts/ datasets/reanalysis-datasets/era5. The TRMM database is provided by the University of Utah via their website (http:// trmm.chpc.utah.edu/).

\section{Conflicts of Interest}

The authors declare that they have no conflicts of interest.

\section{Acknowledgments}

The authors thank the University of Utah for providing the TRMM database via their website (http://trmm.chpc.utah. edu/). This research was funded by the National Natural Science Foundation of China (Grant nos. 41875046, 91837311, and 41630421).

\section{Supplementary Materials}

The code provided in the supplementary material is used to interpolate temporally and spatially the lapse rate tropopause height derived $0.25^{\circ} \times 0.25^{\circ}$, 6-hourly ERA5 and ERA5.1 data to the time and location of each TRMM PF. (Supplementary Materials)

\section{References}

[1] J. R. Holton, P. H. Haynes, M. E. Mcintyre, A. R. Douglass, R. B. Rood, and L. Pfister, "Stratosphere-troposphere exchange," Reviews of Geophysics, vol. 33, no. 4, pp. 403-439, 1995.

[2] X. Qie, X. Wu, T. Yuan, J. Bian, and D. Lu, "Comprehensive pattern of deep convective systems over the Tibetan Plateau-South Asian monsoon region based on TRMM data," Journal of Climate, vol. 27, no. 17, pp. 6612-6626, 2014.

[3] P. Yu, K. H. Rosenlof, S. Liu et al., "Efficient transport of tropospheric aerosol into the stratosphere via the Asian summer monsoon anticyclone," Proceedings of the National Academy of Sciences, vol. 114, no. 27, pp. 6972-6977, 2017.

[4] T. Corti, B. P. Luo, M. deReus et al., "Unprecedented evidence for deep convection hydrating the tropical stratosphere," Geophysical Research Letters, vol. 35, no. 10, pp. 1-5, 2008.

[5] M. De Reus, S. Borrmann, A. Bansemer et al., "Evidence for ice particles in the tropical stratosphere from in-situ measurements," Atmospheric Chemistry and Physics, vol. 9, no. 18, pp. 6775-6792, 2008.

[6] W. Sang, Q. Huang, W. Tian et al., "A large Eddy model study on the effect of overshooting convection on lower stratospheric water vapor," Journal of Geophysical Research, vol. 123, no. 18, pp. 10023-10036, 2018.

[7] P. M. Forster and K. P. Shine, "Assessing the climate impact of trends in stratospheric water vapour," Geophysical Research Letters, vol. 29, no. 6, p. 1086, 2002.

[8] D. B. Kirk-Davidoff, E. J. Hintsa, J. G. Anderson, and D. W. Keith, "The effect of climate change on ozone depletion through changes in stratospheric water vapour," Nature, vol. 402, no. 6760, pp. 399-401, 1999.

[9] J. G. Anderson, D. M. Wilmouth, J. B. Smith, and D. S. Sayres, "UV dosage levels in summer: Increased risk of ozone loss from convectively injected water vapor," Science, vol. 337, no. 6096, pp. 835-839, 2012.

[10] S. Solomon, K. H. Rosenlof, R. W. Portmann et al., "Contributions of stratospheric water vapor to decadal changes in the rate of global warming," Science, vol. 327, no. 5970, pp. 1219-1223, 2010.

[11] G. Wu and Y. Zhang, "Tibetan plateau forcing and the timing of the monsoon onset over south asia and the south China sea," Monthly Weather Review, vol. 126, no. 4, pp. 913-927, 1998.

[12] X. Xu, M. Zhou, J. Chen et al., “A comprehensive physical pattern of land-air dynamic and thermal structure on the Qinghai-Xizang Plateau," Science in China Series D, vol. 45, no. 7, pp. 577-594, 2002, in Chinese.

[13] T. Zhou, R. Yu, H. Chen, A. Dai, and Y. Pan, "Summer precipitation frequency, intensity, and diurnal cycle over China: A comparison of satellite data with rain gauge observations," Journal of Climate, vol. 21, no. 16, pp. 3997-4010, 2008.

[14] X. Zhou, C. Luo, W. Li, and J. Shi, "Ozone changes over China and low center over Tibetan Plateau," Chinese Science Bulletin, vol. 40, pp. 1396-1398, 1995, in Chinese. 
[15] W. Tian, M. Chipperfield, and Q. Huang, "Effects of the Tibetan Plateau on total column ozone distribution," Tellus B: Chemical and Physical Meteorology, vol. 60, no. 4, pp. 622635, 2008.

[16] J. Bian, L. L. Pan, L. Paulik, H. Vömel, H. Chen, and D. Lu, "In situ water vapor and ozone measurements in Lhasa and Kunming during the Asian summer monsoon," Geophysical Research Letters, vol. 39, no. 19, p. 19808, 2012.

[17] J. Zhang, W. Tian, F. Xie et al., "Climate warming and decreasing total column ozone over the Tibetan Plateau during winter and spring," Tellus B, vol. 66, no. 1, 2014.

[18] A. Gettelman, D. E. Kinnison, T. J. Dunkerton, and G. P. Brasseur, "Impact of monsoon circulations on the upper troposphere and low stratosphere," Journal of Geophysical Research: Atmospheres, vol. 109, no. D22, p. 101, 2004.

[19] W. J. Randel and M. Park, "Deep convective influence on the Asian summer monsoon anticyclone and associated tracer variability observed with atmospheric infrared sounder (AIRS)," Journal of Geophysical Research, vol. 111, no. D12, 2006.

[20] W. Tian, H. Tian, S. Dhomse, and W. Feng, "A study of upper troposphere and lower stratosphere water vapor above the Tibetan Plateau using AIRS and MLS data," Atmospheric Science Letters, vol. 12, no. 2, pp. 233-239, 2011.

[21] H. Tian, W. Tian, J. Luo, J. Zhang, and M. Zhang, "Climatology of cross-tropopause mass exchange over the Tibetan Plateau and its surroundings," International Journal of Climatology, vol. 37, no. 11, pp. 3999-4014, 2017.

[22] R. Fu, Y. Hu, J. S. Wright et al., "Short circuit of water vapor and polluted air to the global stratosphere by convective transport over the Tibetan Plateau," Proceedings of the $\mathrm{Na}$ tional Academy of Sciences, vol. 103, no. 15, pp. 5664-5669, 2006.

[23] M. Park, W. J. Randel, A. Gettelman, S. T. Massie, and J. H. Jiang, "Transport above the asian summer monsoon anticyclone inferred from aura microwave limb sounder tracers," Journal of Geophysical Research, vol. 112, no. D16, Article ID D16309, 2007.

[24] W. J. Randel, M. Park, L. Emmons et al., "Asian monsoon transport of pollution to the stratosphere," Science, vol. 328, no. 5978, pp. 611-613, 2010.

[25] Y. Luo, R. Zhang, W. Qian, Z. Luo, and X. Hu, "Intercomparison of deep convection over the Tibetan Plateau-Asian monsoon region and subtropical North America in boreal summer using CloudSat/CALIPSO data," Journal of Climate, vol. 24, no. 8, pp. 2164-2177, 2011.

[26] N. K. Heath and H. E. Fuelberg, "Using a WRF simulation to examine regions where convection impacts the asian summer monsoon anticyclone," Atmospheric Chemistry and Physics, vol. 14, no. 4, pp. 2055-2070, 2014.

[27] X. Chen, B. Škerlak, M. W. Rotach et al., "Reasons for the extremely high-ranging planetary boundary layer over the western Tibetan Plateau in winter," Journal of the Atmospheric Sciences, vol. 73, no. 5, pp. 2021-2038, 2016.

[28] X. Chen, J. A. Añel, Z. Su et al., "The deep atmospheric boundary layer and its significance to the stratosphere and troposphere exchange over the Tibetan plateau," PLoS One, vol. 8, no. 2, Article ID e56909, 2013.

[29] X. Yin, S. Kang, B. de Foy et al., "Surface ozone at Nam Co in the inland Tibetan plateau: Variation, synthesis comparison and regional representativeness," Atmospheric Chemistry and Physics, vol. 17, no. 18, pp. 11293-11311, 2017.

[30] M. A. Goering, W. A. Gallus, M. A. Olsen, and J. L. Stanford, "Role of stratospheric air in a severe weather event: Analysis of potential vorticity and total ozone," Journal of Geophysical Research: Atmospheres, vol. 106, no. D11, pp. 11813-11823, 2001.

[31] M. Griffiths, A. J. Thorpe, and K. A. Browning, "Convective destabilization by a tropopause fold diagnosed using potential-vorticity inversion," Quarterly Journal of the Royal Meteorological Society, vol. 126, no. 562, pp. 125-144, 2000.

[32] J. S. Sawyer, "The structure of the intertropical front over N. W. India during the S.W. Monsoon," Quarterly Journal of the Royal Meteorological Society, vol. 73, no. 317-318, pp. 346-369, 1947.

[33] R. A. Houze, D. Wilton, and B. F. Smull, "Monsoon convection in the Himalayan region as seen by the TRMM precipitation radar," Quarterly Journal of the Royal Meteorological Society, vol. 133, no. 627, pp. 1389-1411, 2007.

[34] L. de la Torre, R. Nieto, M. Noguerol, J. A. Añel, and L. Gimeno, "A climatology based on reanalysis of baroclinic developmental regions in the extratropical northern hemisphere," Annals of the New York Academy of Sciences, vol. 1146, no. 1, pp. 235-255, 2008.

[35] M. P. Baldwin and T. J. Dunkerton, "Propagation of the arctic oscillation from the stratosphere to the troposphere," Journal of Geophysical Research: Atmospheres, vol. 104, no. D24, pp. 30937-30946, 1999.

[36] $\mathrm{Y} . \mathrm{Hu}$, "On the influence of stratospheric anomalies on tropospheric weather systems," Advances in Earth Science, vol. 21, no. 7, pp. 713-720, 2006.

[37] W. Chen and K. Wei, "Interannual variability of the winter stratospheric polar vortex in the northern hemisphere and their relations to QBO and ENSO," Advances in Atmospheric Sciences, vol. 26, no. 5, pp. 855-863, 2009.

[38] S. J. Colucci, "Stratospheric influences on tropospheric weather systems," Journal of the Atmospheric Sciences, vol. 67, no. 2, pp. 324-344, 2010.

[39] Y. Hinssen, A. V. Delden, T. Opsteegh, and W. de Geus, "Stratospheric impact on tropospheric winds deduced from potential vorticity inversion in relation to the Arctic Oscillation," Quarterly Journal of the Royal Meteorological Society, vol. 136, no. 653, pp. 2203-2204, 2010.

[40] D. E. Hartley, J. T. Villarin, R. X. Black, and C. A. Davis, “A new perspective on the dynamical link between the stratosphere and troposphere," Nature, vol. 391, no. 6666, pp. 471-474, 1998.

[41] R. X. Black, "Stratospheric forcing of surface climate in the Arctic Oscillation," Journal of Climate, vol. 15, no. 3, pp. 268-277, 2002.

[42] J. Luo, W. Tian, P. Zhang, J. Hu, and F. Xie, "Analysis of the anomalous signals around the tropopause and in the stratosphere before the Meiyu onset," Acta Meteorological Sinica, vol. 70, no. 4, pp. 655-669, 2012, in Chinese.

[43] M. Sigmond, J. F. Scinocca, and P. J. Kushner, "Impact of the stratosphere on tropospheric climate change," Geophysical Research Letters, vol. 35, no. 12, 2008.

[44] A. A. Scaife, T. Spangehl, D. R. Fereday et al., "Climate change projections and stratosphere-troposphere interaction," Climate Dynamics, vol. 38, no. 9-10, pp. 2089-2097, 2012.

[45] A. Y. Karpechko and E. Manzini, "Stratospheric influence on tropospheric climate change in the northern hemisphere," Journal of Geophysical Research: Atmospheres, vol. 117, no. D5, 2012.

[46] E. Manzini, A. Y. Karpechko, J. Anstey et al., "Northern winter climate change: Assessment of uncertainty in CMIP5 projections related to stratosphere-troposphere coupling," 
Journal of Geophysical Research: Atmospheres, vol. 119, no. 13, pp. 7979-7998, 2014.

[47] J. Kidston, A. A. Scaife, S. C. Hardiman et al., "Stratospheric influence on tropospheric jet streams, storm tracks and surface weather," Nature Geoscience, vol. 8, no. 6, pp. 433-440, 2015.

[48] C. Liu, E. J. Zipser, D. J. Cecil, S. W. Nesbitt, and S. Sherwood, "A cloud and precipitation feature database from nine years of TRMM observations," Journal of Applied Meteorology and Climatology, vol. 47, no. 10, pp. 2712-2728, 2008.

[49] S. W. Nesbitt, E. J. Zipser, and D. J. Cecil, "A census of precipitation features in the tropics using TRMM: Radar, ice scattering, and lightning observations," Journal of Climate, vol. 13, no. 23, pp. 4087-4106, 2000.

[50] E. J. Zipser, D. J. Cecil, C. Liu, S. W. Nesbitt, and D. P. Yorty, "Where are the most intense thunderstorms on earth?" Bulletin of the American Meteorological Society, vol. 87, no. 8, pp. 1057-1072, 2006.

[51] C. Liu and E. J. Zipser, "Global distribution of convection penetrating the tropical tropopause," Journal of Geophysical Research, vol. 110, no. D23, pp. 1-12, 2005.

[52] N. Liu and C. Liu, "Synoptic environments and characteristics of convection reaching the tropopause over Northeast China," Monthly Weather Review, vol. 146, no. 3, pp. 745-759, 2018.

[53] WMO, "Meteorology-A three-dimensional science: Second session of the commission for aerology," WMO Bulletin, vol. IV, no. 4, pp. 134-138, 1957.

[54] N. Liu and C. Liu, "Global distribution of deep convection reaching tropopause in 1 year GPM observations," Journal of Geophysical Research: Atmospheres, vol. 121, no. 8, pp. 3824-3842, 2016.

[55] D. L. Solomon, K. P. Bowman, and C. R. Homeyer, "Tropopause-penetrating convection from three-dimensional gridded NEXRAD data," Journal of Applied Meteorology and Climatology, vol. 55, no. 2, pp. 465-478, 2016.

[56] L. Hoffmann, G. Günther, D. Li et al., "From ERA-Interim to ERA5: The considerable impact of ECMWF's next-generation reanalysis on Lagrangian transport simulations," Atmospheric Chemistry and Physics, vol. 19, no. 5, pp. 3097-3124, 2019.

[57] A. Simmons, C. Soci, J. Nicolas et al., "Global stratospheric temperature bias and other stratospheric aspects of ERA5 and ERA5.1," Technical memorandum, vol. 859, 2020.

[58] X. L. Chen, Y. M. Ma, H. Kelder, Z. Su, and K. Yang, "On the behaviour of the tropopause folding events over the Tibetan plateau," Atmospheric Chemistry and Physics, vol. 11, no. 10, pp. 5113-5122, 2011.

[59] M. A. Shapiro, "Further evidence of the mesoscale and turbulent structure of upper level jet stream-frontal zone systems," Monthly Weather Review, vol. 106, no. 8, pp. 1100-1111, 1978.

[60] M. A. Shapiro, "Turbulent mixing within tropopause folds as a mechanism for the exchange of chemical constituents between the stratosphere and troposphere," Journal of the Atmospheric Sciences, vol. 37, no. 5, pp. 994-1004, 1980.

[61] P. Xu, A Study on the Changes of Tropopause Folds and its Impact on the Ozone over the Tibetan Plateau, pp. 1-86, Lanzhou University, Lanzhou, China, 2015, in Chinese.

[62] E. F. Danielsen, "Stratospheric-tropospheric exchange based on radioactivity, ozone and potential vorticity," Journal of the Atmospheric Sciences, vol. 25, no. 3, pp. 502-518, 1968.

[63] C. Appenzeller and H. C. Davies, "Structure of stratospheric intrusions into the troposphere," Nature, vol. 358, no. 6387, pp. 570-572, 1992.
[64] G. Ancellet, M. Beekmann, and A. Papayannis, "Impact of a cutoff low development on downward transport of ozone in the troposphere," Journal of Geophysical Research, vol. 99, no. D2, p. 3451, 1994.

[65] G. Ancellet, J. Pelon, M. Beekmann, A. Papayannis, and G. Megie, "Ground-based lidar studies of ozone exchanges between the stratosphere and the troposphere," Journal of Geophysical Research, vol. 96, no. D12, pp. 22401-22421, 1991.

[66] G. Vaughan, J. D. Price, and A. Howells, "Transport into the troposphere in a tropopause fold," Quarterly Journal of the Royal Meteorological Society, vol. 120, no. 518, pp. 1085-1103, 1994.

[67] H. Eisele, H. E. Scheel, R. Sladkovic, and T. Trickl, "Highresolution lidar measurements of stratosphere-troposphere exchange," Journal of the Atmospheric Sciences, vol. 56, no. 2, pp. 319-330, 1999.

[68] A. S. Kentarchos, T. D. Davies, and C. S. Zerefos, "A low latitude stratospheric intrusion associated with a cut-off low," Geophysical Research Letters, vol. 25, no. 1, pp. 67-70, 1998.

[69] A. S. Kentarchos, G. J. Roelofs, and J. Lelieveld, "Model study of a stratospheric intrusion event at lower midlatitudes associated with the development of a cutoff low," Journal of Geophysical Research: Atmospheres, vol. 104, no. D1, pp. 1717-1727, 1999.

[70] M. Zhang, W. Tian, L. Chen, and D. Lü, "Cross-tropopause mass exchange associated with a tropopause fold event over the northeastern Tibetan Plateau," Advances in Atmospheric Sciences, vol. 27, no. 6, pp. 1344-1360, 2010.

[71] B. J. Hoskins, M. E. McIntyre, and A. W. Robertson, "On the use and significance of isentropic potential vorticity maps," Quarterly Journal of the Royal Meteorological Society, vol. 111, pp. 877-946, 1985.

[72] A. Russell, G. Vaughan, and E. G. Norton, "Large-scale potential vorticity anomalies and deep convection," Quarterly Journal of the Royal Meteorological Society, vol. 138, no. 667, pp. 1627-1639, 2012.

[73] R. J. Reed, "A study of a characteristic tpye of upper-level frontogenesis," Journal of Meteorology, vol. 12, no. 3, pp. 226-237, 1955.

[74] B. D. Cox, M. Bithell, and L. J. Gray, "A general circulation model study of a tropopause-folding event at middle latitudes," Quarterly Journal of the Royal Meteorological Society, vol. 121, no. 524, pp. 883-910, 1995.

[75] K. A. Browning and N. M. Roberts, "Use of satellite imagery to diagnose events leading to frontal thunderstorms: Part I of a case study," Meteorological Applications, vol. 1, no. 4, pp. 303-310, 2007.

[76] P. E. Ciesielski and R. H. Johnson, "Contrasting characteristics of convection over the northern and southern South China Sea during SCSMEX," Monthly Weather Review, vol. 134, no. 4, pp. 1041-1062, 2006.

[77] C. Morcrette, H. Lean, K. Browning et al., "Combination of mesoscale and synoptic mechanisms for triggering an isolated thunderstorm: Observational case study of CSIP IOP 1," Monthly Weather Review, vol. 135, no. 11, pp. 3728-3749, 2007. 